TAHKIM, Jurnal Peradaban dan Hukum Islam. Vol.3 No.2 (0ktober, 2020) | ISSN : 2597-7962

\title{
HUKUMAN MATI BAGI TERPIDANA NARKOBA MENURUT HUKUM POSITIF DAN HUKUM PIDANA ISLAM
}

\author{
Yandi Maryandi \\ Fakultas Syariah Universitas Bandung \\ Yandi140985@gmail.com
}

\begin{abstract}
ABSTRAK
Di Indonesia, ketentuan mengenai tindak pidana narkoba diatur oleh Undang-Undang Nomor 35 Tahun 2009 tentang Narkotika serta Undang-Undang Nomor 5 Tahun 1997 tentang Psikotropika. Dalam Undang-Undang tersebut terdapat beberapa sanksi pidana bagi para pelaku penyalahgunaan narkoba, seperti pidana penjara, penjara seumur hidup, denda bahkan sanksi pidana mati. Mengenai sanksi pidana mati (salah satunya Nomor 35 Tahun 2009 tentang Narkotika) terdapat pro dan kontra dari para ahli mengenai hal tersebut. Salah satu bentuk sanksi yang paling berat ialah pidana mati dan telah diperdebatkan ratusan tahun lamanya oleh ahli hukum pidana dan kriminologi. Narkoba dalam konteks hukum Islam adalah termasuk masalah ijtihâdî, karena narkoba tidak disebutkan secara langsung mengenai pengharamannya oleh nash baik Al-Qur'an ataupun al-Sunnah, pada masa Rasulullah Saw ketika itu hanya dikenal dengan istilah khamr. Tujuan Penelitian adalah untuk mengetahui tentang sanksi pidana bagi para pelaku penyalahgunaan narkoba persfektif Hukum Positif dan Hukum Pidana Islam. Metodologi penelitian yang digunakan adalah metode penelitian kualitatif melalui studi kepustakaan, dengan jenis penelitian yuridis normative. Penerapan sanksi pidana mati diberikan kepada Pembuat, Bandar dan pengedar sesuai Undang-Undang No.35 Tahun 2009 Tentang Narkotika. Hukum narkotika adalah haram sama halnya dengan haramnya khamr, salah satu sanksi pidananya adalah hukuman mati dengan pendekatan hirabah karena efek yang ditimbulkan narkotika dari segala aspek.
\end{abstract}

\section{Kata Kunci: Narkoba, Pidana Mati, Pidana Islam}

\section{ABSTRACT}

In Indonesia, provisions regarding criminal acts are regulated by Law Number 35 of 2009 concerning Narcotics and Law Number 5 of 1997 concerning Psychotropics. In this Law, there are several criminal sanctions for criminals, such as imprisonment, fines and capital punishment. Regarding criminal sanctions (one of which is in Number 35 of 2009 concerning Narcotics) there are pros and cons from experts regarding this matter. One of the most severe forms of death penalty and has been debated for hundreds of years by criminal law and criminology experts. Narcotics in the context of Islamic law is a matter of 
ijtihâdî, because drugs do not enter directly into their prohibition by the texts of either the Al-Qur'an or al-Sunnah, and were not known at the time of the Prophet Muhammad at that time who were in the community from khamr drinkers. The research objective is to find out about the sanctions for the perpetrators of drug crime from the perspective of positive law and Islamic criminal law. The research methodology used is qualitative research through literature study, with the type of juridical normative research. The application of criminal sanctions given to manufacturers, dealers and dealers in accordance with Law No.35 of 2009 on Narcotics. The law on narcotics is haram as well as related to the haram of khamr, one of the penal sanctions is the death penalty using the hirabah approach because of the effects of narcotics from all aspects.

\section{Keywords: Drugs, Criminal Death, Islamic Criminal}

\section{A. PENDAHULUAN}

Sampai saat ini para ahli hukum (positif) masih terdapat pro-kontra terhadap penerapan pidana mati di Indonesia. Dari pihak-pihak yang berargumentasi bahwa pidana mati itu lebih efektif dan sesuai dengan perikemanusiaan. Sementara mereka yang kontra mengatakan bahwa pidana mati itu tidaklah selalu lebih efektif, dan justru malah melanggar nilai-nilai kemanusiaan.

Tindak pidana narkoba di Indonesia diatur dalam Undang-Undang Nomor 35 Tahun 2009 tentang Narkoba. Dalam undang-undang tersebut, terdapat beberapa jenis sanksi pidana bagi para terpidana narkotika, seperti pidana penjara (minimum-maksimum), pidana penjara seumur hidup, pidana denda dan yang paling berat dan masih kontroversial sehingga memunculkan pro dan kontra adalah sanksi pidana mati.

Pemberlakuan pidana mati terhadap kejahatan-kejahatan tertentu dalam UndangUndang Narkotika tidak bertentangan dengan UUD 1945. Ancaman pidana mati yang dimuat dalam pasal-pasal pidana Undang-Undang tentang Narkotika juga memberikan ancaman hukuman pidana minimal khusus. Artinya, dalam menjatuhkan hukuman pada pelaku pelanggaran pasal-pasal Narkotika Golongan I tersebut, hakim berdasarkan alat bukti yang ada dan keyakinannya dapat menghukum pelakunya dengan ancaman maksimalnya, yaitu 
TAHKIM, Jurnal Peradaban dan Hukum Islam. Vol.3 No.2 (0ktober, 2020) | ISSN : 2597-7962

pidana mati. Sebaliknya, kalau berkeyakinan bahwa sesuai dengan bukti yang ada, unsur sengaja dan tidak sengaja, pelakunya di bawah umur, pelakunya perempuan yang sedang hamil, dan sebagainya, maka kepada pelakunya tidak bisa dijatuhi pidana mati. Dengan demikian, jelaslah bahwa pemberlakuan pidana mati dalam kasus kejahatan Narkotika tidaklah boleh sewenang-wenang diterapkan oleh hakim.

Sejumlah ahli baik dari kalangan akademisi, praktisi dan aparat penegak hukum dihadirkan dalam sidang pengujian Undang-Undang tentang Narkotika tersebut. Berbagai pendapat dilontarkan yang semuanya hampir sama-sama kuat dan logis. Terdapat dua arus pemikiran; yaitu: pertama, mereka yang kontra pidana mati, kedua, mereka yang pro pidana mati.

Sama halnya dengan para pakar hukum pidana positif, dalam hukum pidana Islam hukuman mati sebagai ta'zîr (lain halnya dengan tindak pidana qishsâsh dan hudûd yang sudah disepakati oleh para ulama) menjadi bahan perdebatan para fukaha. Ada yang membolehkan dan ada pula yang melarang karena tidak sesuai dengan tujuan pemidanaan ta'zîr, yaitu al-ta'dîb.

Mengenai eksistensi hukuman mati sebagai qishsâsh dan hudûd memang sudah disepakati oleh para fukaha (ulama). Hukuman mati sebagai qishsâsh pada tindak pidana pembunuhan disebutkan secara tegas dalam Al-Qur'ân. Demikian juga sanksi hukuman mati sebagai hudûd bagi pelaku tindak pidana, yaitu pada tindak pidana pezina muhson perampokan, pemberontakan dan murtad.

Akan tetapi, hukuman mati sebagai ta'zîr tidak sebulat kesepakatan ulama dalam hal hukuman mati sebagai qishsâsh dan $\underline{h} u d \hat{u} d$. Terdapat dua pendapat dalam hal ini, ada ulama membolehkan hukuman pidana mati sebagai ta'zîr dan ada pula ulama yang menolak hukuman pidana mati sebagai ta'zîr. 
TAHKIM, Jurnal Peradaban dan Hukum Islam. Vol.3 No.2 (0ktober, 2020) | ISSN : 2597-7962

\section{B. METODE PENELITIAN}

\section{Metode Penelitian}

Metode penelitian yang digunakan adalah metode penelitian kualitatif. Gaya" penelitian kualitatif berusaha mengkonstruksi realitas dan memahami maknanya. Sehingga, penelitian kualitatif biasanya sangat memperhatikan proses, peristiwa dan otentisitas. Memang dalam penelitian kualitatif kehadiran nilai peneliti bersifat eksplisit dalam situasi yang terbatas, melibatkan subjek dengan jumlah relatif sedikit. Dengan demikian, hal yang umum dilakukan ia berkutat dengan analisa tematik. Peneliti kualitatif biasanya terlibat dalam interaksi dengan realitas yang ditelitinya. ${ }^{1}$

Pendekatan penelitian ini adalah penelitian kualitatif, melalui pendekatan penelitian hukum yuridis normatif yang mencakup penelitian terhadap asas-asas hukum, sistematika hukum, taraf sinkronisasi hukum, sejarah hukum dan perbandingan hukum.

Spesifikasi penelitian ini adalah penelitian deskriptif analitis yang merupakan penelitian untuk menggambarkan dan menganalisa masalah yang ada dan termasuk dalam jenis penelitian kepustakaan (library research) yang akan disajikan secara deskriptif.

Penelitian hukum yuridis normatif ini, data yang diperlukan berupa data sekunder atau data kepustakaan dan dokumen hukum yang berupa bahan-bahan hukum. Yang dipergunakan dalam penelitian ini adalah studi kepustakaan (library research) yaitu jenis penelitian yang data-datanya diperoleh dari buku, kitab, majalah, surat kabar, jurnal dan catatan lainnya yang memiliki relevansi dengan permasatanah yang akan dibahas.

\footnotetext{
${ }^{1}$ Gumilar Rusliwa Somantri, "Memahami Metode Kualitatif," Makara Hubs Asia, Vol. 9, Desember
} 2005 . 


\section{PEMBAHASAN}

\section{Penerapan Hukuman Mati di Indonesia}

Hukuman mati di Indonesia sudah lama berlangsung, yaitu sejak bangsa Indonesia dijajah Belanda, hingga sampai sekarang masih tetap diberlakukan walaupun di Negara Belanda telah menghapuskan pidana mati mulai tahun 1987. KUHP (Wetboek Van Strafrecht) disahkan pada tanggal 1 Januari 1981. Menurut ahli-ahli pidana pada saat itu, dipertahankannya pidana mati karena keadaan khusus di Indonesia menuntut supaya penjahat-penjahat yang terbesar bisa dilawan dengan pidana mati. Dengan wilayah yang begitu luas dengan penduduk yang heterogen, alat Kepolisian Negara tidak bisa menjamin keamanan. Perbuatan-perbuatan atau tindak pidana yang diancam dengan pidana mati oleh KUHP, antara lain: Pasal 104, Pasal 111 ayat (2), Pasal 124 ayat (3), Pasal 140 ayat (3), Pasal 340, Pasal 365 ayat (4), Pasal 368 , Pasal 444 KUHP, Pasal 479 K ayat (2) dan Pasal 479 o ayat (2). Di samping itu hukuman mati di Indonesia juga dijelaskan dalam perundangan di luar KUHP, yaitu: a) Undang-Undang Nomor 5 Tahun 1997 tentang Psikotropika Pasal 59 ayat (2); b) Pasal 36 Undang-Undang Nomor 26 Tahun 2000 Tentang Pengadilan Hak Asasi Manusia; c) Pasal 2 ayat (2) Undang-Undang Nomor 20 tahun 2001 tentang Perubahan atas UndangUndang Nomor 31 Tahun 1999 tentang Pemberantasan Tindak Pidana korupsi; d) Pasal 6 Undang-Undang Nomor 15 tahun 2003 tentang Penetapan Peraturan Pemerintah Pengganti Undang-Undang Nomor 1 Tahun 2002 tentang Pemberantasan Tindak Pidana Terorisme; e) Undang-Undang Nomor 35 Tahun 2009 tentang Narkotika: Pasal 113 ayat (2), Pasal 114 ayat (2), Pasal 118 ayat (2), Pasal 119 ayat (2), Pasal 121 ayat (2), Pasal 144 ayat (2). ${ }^{2}$

Meski hukuman mati masih berlangsung dan belum dihapuskan di Indonesia, masyarakat berbeda pendapat dalam menanggapinya seiring dengan banyaknya negaranegara yang menghapuskan hukuman mati tersebut. Di satu pihak, ada kelompok masyarakat

\footnotetext{
${ }^{2}$ Agus Purnomo, "Hukuman Mati Bagi Tindak Pidana Narkoba di Indonesia : Persfektif Sosiologi Agama," De Jure : Jurnal Hukum dan Syariah, vol. 8, Juni 2016, hlm 17.
} 
menyatakan dukungannya bahwa hukuman mati masih diperlukan di Indonesia terlebih lagi secara yuridis masih diakui. Sementara itu, di pihak lain terdapat kelompok masyarakat yang menginginkan agar hukuman mati dihapuskan.

Menurut hasil survei nasional Indo Barometer yang diselenggarakan pada tanggal 1525 Maret 2015, mayoritas publik di Indonesia, yakni sekitar 84,1 persen menyatakan setuju dengan hukuman mati bagi para pengedar narkoba. "Bagi mereka yang setuju, alasan yang banyak diungkap adalah bahwa narkoba merusak generasi muda (60,8\%), dan dapat menyebabkan efek jera (23,7\%)," demikian tutur Qodari. Adapun publik yang tidak setuju, alasan yang banyak diungkap adalah karena menurut mereka masih ada jenis hukuman lain yang lebih manusiawi $(36,2 \%)$, sementara hukuman mati justru merupakan pelanggaran terhadap hak asasi manusia (28, 4\%).11Sementara itu, lanjut Qodari, sebagian besar atau sekitar 84,6\% masyarakat Indonesia mendukung langkah Presiden Jokowi dalam menerapkan hukuman mati bagi pengedar narkoba, sedangkan yang tidak mendukung hanya 10,3 persen. Mayoritas publik (86, 3\%) menyatakan bahwa Presiden Jokowi sebaiknya tetap melanjutkan hukuman mati terhadap terpidana kasus narkoba, meski berimplikasi ada negara lain yang akan memutuskan hubungan diplomatik dan menghentikan kerjasama ekonomi dengan Negara Indonesia. ${ }^{3}$

\section{Bandar Narkoba dan Jenis Peredaran Gelap Narkoba}

Menurut Kamus Besar Bahasa Indonesia (KBBI ), Bandar adalah orang yang mengendalikan suatu aksi (gerakan) dengan sembunyi-sembunyi. Bandar narkotika dapat diartikan sebagai orang yang mengendalikan suatu aksi kejahatan narkotika secara sembunyisembunyi atau sebagai pihak yang membiayai aksi kejahatan itu. Dalam praktiknya, bandar narkotika itu antara lain: orang yang menjadi otak di balik penyelundupan narkotika, permufakatan kejahatan narkotika, dan sebagainya. Secara sempit dapat dikatakan bahwa

\footnotetext{
${ }^{3} \mathrm{Ibid}$.
} 
pengedar Narkotika/Psikotropika adalah orang yang melakukan kegiatan penyaluran dan penyerahan Narkotika/Psikotropika. Pengedar belum tentu berarti bandar narkotika.

Dalam kasus tindak pidana narkoba yang dianggap sebagai kejahatan yang paling serius dan bahkan akibat yang ditimbulkan dapat menghancurkan masa depan anak bangsa. Namun, dalam sejumlah penelitian menunjukkan, ternyata tidak ada korelasi positif antara hukuman mati dengan berkurangnya tingkat kejahatan tersebut, di Indonesia justru menunjukkan peningkatan dari pengguna dan pengedar, sampai pada adanya produsen. Dalam kaitan ini, upaya penanggulangan narkoba di negara-negara maju sudah mulai dilakukan dengan meningkatkan pendidikan sejak dini dan melakukan kampanye anti narkoba, serta penyuluhan tentang bahayanya. Demikian seriusnya penanggulangan masalah narkoba bagi kehidupan manusia sudah mendorong kerja sama internasional dalam memerangi kejahatan narkoba tersebut. ${ }^{4}$

Karena kejahatan narkoba itu bukan hanya membunuh hidup, tetapi membunuh kehidupan manusia, bahkan masyarakat luas. Kejahatan narkoba itu bukan hanya menghilangkan belasan ribu nyawa manusia setiap tahun, tetapi menghancurkan kehidupan dan masa depan generasi penerus bangsa. Kalau ingin bangsa dan negara ini selamat, kita tak boleh toleran terhadap kejahatan narkoba, korupsi, dan terorisme.

Hukuman mati dilakukan dengan berbagai cara di dunia. Dahulu hukuman mati dipandang relevan dan sah dilakukan secara terbuka di depan umum, dengan cara dipancung, dibakar, atau bahkan disiksa hingga mati. Di hamper seluruh dunia, hukuman mati dilakukan untuk kejahatan - kejahatan subversif berupa penghinaan terhadap Raja atau Pimpinan Agama, kejahatan perang dan pemberontakan, kriminalitas yang disertai dengan kekejaman, dan lain-lain.

${ }^{4}$ Arif Barda, Bunga Rampai Kebijakan Hukum Pidana. Bandung, (Indonesia: PT Citra Aditya Bakti, 2002). Hlm. 56. 
Hukuman mati merupakan salah satu tujuan dari pemidanaan untuk mencegah dan menimbulkan efek jera para pelaku tindak pidana. Menurut Muzakir dalam "Kutipan Putusan Mahkamah Konstitusi Republik Indonesia Nomor 2-3/PUU-V/2007 mengenai Pengujian Undang- Undang Nomor 22 Tahun 1997 tentang Narkotika terhadap UUD 1945" pidana mati dijatuhkan sebagai upaya terakhir untuk mengayomi masyarakat, jadi untuk memberi proteksi pada asas perlindungan masyarakat. Inti dari pidana mati atau hukuman mati sebenarnya untuk mengayomi masyarakat, yaitu untuk memberikan saluran kepada masyarakat yang ingin membalas dendam. Sebab jika tidakada saluran lewat perundangundangan yakni lewat hukum pidana, dikhawatirkan masyarakat akan mengambil tindakan main hakim sendiri.

\section{Penegakan Hukuman Mati Bagi Terpidana Narkoba}

Indonesia saat ini sudah dalam keadaan darurat nakotika. Penjahat narkotika seakan tidak peduli akan ancaman sanksi pidananya. Ancaman sanksi pidana mati adalah hukuman yang paling berat dengan harapan membuat jera bagi pelaku lain. Selama hukum diterapkan secara adil dan konsisten pasti masyarakat akan merasakan keadilan, kepastian dan kemanfatan.

Kebijakan hukum pidana terhadap tindak pidana Narkotika yang dapat diancam sanksi pidana mati menurut UU No. 35 tahun 2009 tentang Narkotika antara lain :

a. Berlakunya hukum pidana menurut tempat diperluas dengan Pasal 145 UU tersebut yang berbunyi : Setiap orang yang melakukan tindak pidana Narkotika dan/atau tindak pidana Prekursor Narkotika sebagaimana dimaksud dalam Pasal 111, Pasal 112, Pasal 113, Pasal 114, Pasal 115,Pasal 116, Pasal 117, Pasal 118, Pasal 119, Pasal 120, Pasal121, Pasal 122, Pasal 123, Pasal 124, Pasal 125, Pasal 126,Pasal 127 ayat (1), Pasal 128 ayat (1), dan Pasal 129 di luar wilayah Negara Republik Indonesia diberlakukan juga ketentuan UU ini.

b. Perbuatan tanpa hak dan melawan hukum memproduksi, mengimpor, mengekspor, atau menyalurkan narkotika golongan I, II, III (Pasal 113,118,123). 
TAHKIM, Jurnal Peradaban dan Hukum Islam. Vol.3 No.2 (0ktober, 2020) | ISSN : 2597-7962

Dari Pasal-Pasal Undang-UndangNarkotika yang mengatur sanksi pidana mati diberikan terhadap kejahatan atau perbuatan yang diberikan sanksi pidana mati pada dasarnya merupakan kejahatan berat dan serius, sangat membahayakan kehidupan manusia, merusak generasi bangsa seperti pembuat, bandar dan pengedar narkotika.

Kebijakan Bangsa Indonesia masih tetap menggunakan dan mempertahankan sanksi pidana mati sebagai salah satu jenis pidana yang terberat. Sanksi pidana mati tersebut dituangkan di dalam RUU KUHP Tahun 2015 Pasal 67 merupakan pidana pokok yang bersifat khusus dan selalu dicantumkan secara alternatif. Pasal 67 berbunyi : Pidana mati merupakan pidana pokok yang bersifat khusus dan selalu diancamkan secara alternatif. Sanksi pidana mati bersifat khusus yaitu pidana mati dicantumkan tersendiri untuk menunjukkan bahwa jenis pidana mati ini benar-benar bersifat khusus. Jika dibandingkan jenis pidana yang lain pidana mati merupakan jenis pidana yang paling berat. Pidana mati dikeluarkan dari stelsel pidana pokok yang diatur dalam ketentuan umum KUHP dan mencantumkannya sebagai pidana pokok yang bersifat khusus atau sebagai pidana eksepsional (perkecualian). Penempatan pidana mati terlepas dari paket pidana pokok dipandang penting, karena merupakan kompromi dari pandangan yang menolak (retensionis) dan yang menerima (abolisionis) hukuman mati. ${ }^{5}$

Sanksi pidana mati selalu diancamkan secara alternatif dengan jenis pidana lainnya yakni pidana seumur hidup atau pidana prenjara paling lama 20 tahun. Pidana mati dikeluarkan dari stelsel pidana pokok yang diatur dalam ketentuan umum KUHP dan mencantumkannya sebagai pidana pokok yang bersifat khusus atau sebagai pidana eksepsional (perkecualian). Penempatan pidana mati terlepas dari paket pidana pokok dipandang penting, karena merupakan kompromi dari pandangan yang menolak (retensionis) dan yang menerima (abolisionis) hukuman mati. ${ }^{6}$

${ }^{5}$ Muhammad H Abdurrahim, "Hukuman Mati Problem Legalitas dan Kemanusiaan," Jurnal Transisi, Vol. X, Januari 2016, hlm 37.

${ }^{6}$ Ibid., 
TAHKIM, Jurnal Peradaban dan Hukum Islam. Vol.3 No.2 (0ktober, 2020) | ISSN : 2597-7962

c. Sanksi Pidana mati merupakan pidana alternatif karena pidana mati adalah pidana paling yang berat oleh karena itu harus selalu selalu diancamkan secara alternative dengan jenis pidana lainnya yaitu pidana seumur hidup atau pidana penjara paling lama 20 ( dua puluh ) tahun. Sesuai Pasal 87 RUU KUHP tahun 2015 bahwa : Pidana mati secara alternative dijatuhkan sebagai upaya terakhir untuk mengayomi masyarakat.

Dalam penjelasan pasal tersebut diuraikan : Pidana mati ini ditekankan sifat kekhususan pidana mati yaitu hanya dapat dijatuhkan sebagai upaya terakhir untuk mengayomi masyarakat. Sanksi pidana Mati dalam RUU KUHP tahun 2015 menganut Asas Keseimbangan. Asas Keseimbangan dituangkan dalam kosideran huruf c yang menyatakan dengan tegas bahwa dalam setiap penegakan hukum harus berlandaskan prinsip keseimbangan yang serasi antara dua kepentingan, yakni :

a. Perlindungan terhadap harkat dan martabat manusia (HAM), dengan;

b. Perlindungan terhadap kepentingan dan ketertiban masyarakat.

Konsep KUHP baru dalam hukum pidana material sebagai pokok pemikirannya adalah Ide keseimbangan yang mencakup antara lain $:^{7}$

a. Keseimbangan monodualistik antara kepentingan umum / masyarrakat dan kepentingan individu / perorangan.

b. Keseimbangan antara perlindungan / kepentingan pelaku tindak pidana dan korban tindak pidana, keseimbangan antara unsur atau faktor / objek (perbuatan lahiriah) dan subjektif.

c. Keseimbanagan antara kreteria formal dan material.

d. Keseimbanagan kepastian hukum, kelenturan / elastisitas / fleksibilitas dan kesadilan.

e. Keseimbangan nilai-nilai nasional dan nilai-nilai global / internasional / universal.

\footnotetext{
${ }^{7}$ Agus Purnomo, Hukuman Mati Bagi Tindak Pidana Narkoba di Indonesia...., hlm 17.
} 
TAHKIM, Jurnal Peradaban dan Hukum Islam. Vol.3 No.2 (0ktober, 2020) | ISSN : 2597-7962

Pidana pada hakikatnya hanya merupakan alat untuk mencapai tujuan. Dalam mengidentifikasi tujuan pemidanan, konsep bertolak dari keseimbangan dua sasaran pokok yaitu: ${ }^{8}$ Perlindungan masyarakat dan perlindungan / pembianaan individu pelaku tindak pidana. Dua pokok mati dan penjara seumur hidup. Upaya perlidungan masyarakat lebih menitik beratkan pada kepentingan masyarakat. Menurut Barda Nawawi Arief dapat dimaklumi dengan alasan bahwa apabila dilihat dari tujuan pemidanaan, pidana mati pada hakikatnya bukan sarana utama/pokok untuk mengatur, menertibkan, dan memperbaiki individu/ masyarakat. Pidana mati hanya merupakan sarana terakhir/perkecualian. Hal ini diidentikkan dengan "amputasi/ operasi" di bidang kedokteran, yang pada hakikatnya juga bukan sarana/obat utama, melainkan hanya upaya perkecualian sebagai sarana/obat terakhir. Oleh karena itu dapat ditegaskan dalam Konsep bahwa "pidana mati secara alternative dijatuhkan sebagai upaya terakhir untuk mengayomi masyarakat". 9

Dari pasal-pasal dan penjelasan tersebut, maka sanksi pidana mati dapt diidetifikasikan kebijakan hukum pidan dalam konsep RUU KUHP Tahun 2015 adalah sebagai berikut :

a. Pidana mati tetap dipertahankan sebagai pidana khusus / eksepsional dan tidak dapat dijatuhkan terhadap anak.

b. Pidana mati merupakan pidana alternatif yang digunakan sangat selektif dan sebagai upaya terakhir.

\section{Dasar-Dasar (Alasan) Sanksi Pidana Mati pada Tindak Pidana Narkotika}

Kejahatan Narkotika termasuk pembuat, bandar dan pengedar sangat membahayakan kehidupan manusia, masyarakat, bangsa dan negara sehingga termasuk kejahatan yang berat dan serius. Penyalahgunaan dan peredaran gelap Narkotika kian menjalar ke seluruh lapisan masyarakat dari tingkat elit sampai ke masyarakat desa. Narkotika merusak sumber daya

\footnotetext{
8 Ibid.,

9 Nawawi Arif Barda, Pembaharuan Hukum Pidana Dalam Perspektif Kajian Perbandingan. (Bandung, : PT Citra Aditya Bakti, 2005), Hlm 56
} 
manusia sebagai salah satu modal pembangunan nasional, oleh karena itu penyalahgunaan dan pemberantasan narkotika harus sungguh-sungguh ditindak tegas oleh para penegak hukum dan seluruh lapisan masyarakat untuk menyelamatkan Indonesia dari bahaya Narkotika. Dalam pemidanaan tindak pidana Narkotika bangsa Indonesia selalu mempertimbangkan Hak Asasi Manusia. HAM merupakan hak negatif (negative right) karena sifatnya yang kodrati dan universal, sehingga tidak memerlukan pengesahan, namun dalam kehidupan bermasyarakat, berbangsa dan benegara yang semakin komplek, pengaturan hukum terhadap HAM (positivization of right) akan memoperkuat posisi Indonesia sebagai negara hukum. ${ }^{10}$

Pertimbangan yang menjadi dasar penetapan UU Nomor 35 Tahun 2009 Tentang Narkotika dalam pengaturan tindak pidana narkotika adalah sebagai berikut :

a. Bahwa mengimpor, mengekspor, memproduksi, menanam, menyimpan, mengedarkan, dan/atau menggunakan Narkotika tanpa pengendalian dan pengawasan yang ketat dan saksama serta bertentangan dengan peraturan perundang-undangan merupakan tindak pidana Narkotika karena sangat merugikan dan merupakan bahaya yang sangat besar bagi kehidupan manusia, masyarakat, bangsa, dan negara serta ketahanan nasional Indonesia;

b. Bahwa tindak pidana Narkotika telah bersifat transnasional yang dilakukan dengan menggunakan modus operandi yang tinggi, teknologi canggih, didukung oleh jaringan organisasi yang luas, dan sudah banyak menimbulkan korban, terutama di kalangan generasi muda bangsa yang sangat membahayakan kehidupan masyarakat, bangsa, dan Negara sehingga Undang- Undang Nomor 22 Tahun 1997 tentang Narkotika sudah tidak sesuai lagi dengan perkembangan situasi dan kondisi yang berkembang untuk menanggulangi dan memberantas tindak pidana tersebut.

${ }^{10}$ Muladi, “Hak Asasi Manusia, Politik dan dan Sistim Peradilan “, (Semarang, Undip, 1997), hlm. 6 
TAHKIM, Jurnal Peradaban dan Hukum Islam. Vol.3 No.2 (0ktober, 2020) | ISSN : 2597-7962

\section{Pengertian Hukum Pidana Islam}

Tindak pidana dalam istilah fiqh (hukum Islam) disebut dengan jināyah, tetapi para ulama fiqh juga memakai Jarīmah. Al-Mawardi mendefinisikan Jarīmah (jināyah) dengan larangan-larangan syara' yang diancam oleh Allah SWT dengan hukuman had atau ta'zīr. ${ }^{11}$ Dalam definisi yang dikemukakan oleh al-Mawardi tidak terlihat adanya tindak pidana yang diancam dengan hukuman qişāşs/diyāt, yang tergambar hanyalah tindak pidana yang diancam hukuman had dan $t a{ }^{\prime} z \bar{\imath} r{ }^{12}$

Muhammad al-Zahrah mengutip definisi tersebut dalam kitab "al-Jarīmatu wa al'Uqubatu fi al-Fiqhi al-Islam $\vec{\imath}$ ', dengan memberikan penjelasan bahwa, hukuman qiş̄̄şs/diyāt tidak disebut karena yang dikatakan hudūd adalah hukuman yang sudah tertentu dan termasuk ke dalamnya qişāş dan diyāt yang kadarnya telah diten tukan syari' di dalam AlQur'ān dan Al-Hadīts.

Hal ini menurut pandangan Muhammad Abu al-Zahrah yang menyatakan bahwa para fuqahā menkatagorikan Jarīmah itu hanya kepada dua macam saja, yaitu Jarīmah hudūd dan Jarimah ta'zīr. ${ }^{13}$ Namun demikian, nampaknya ia tidak setuju dengan katagori tersebut, sebagaimana tergambar dalam penjelasannya tentang makna hudūd. Ia berkata, bahwa pengertian hudūd menurut istilah adalah hukuman yang sudah tertentu dan merupakan hak Allah. Sedangkan qişāş/diyāt tidak dinamakan hudūd karena merupakan hak hamba,

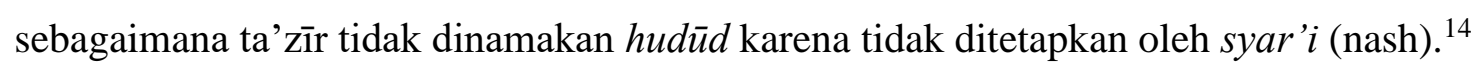

\footnotetext{
${ }^{11}$ Abi al-Hasan 'Ali bin Muhammad bin Habibi al-Busdi al-Mawardi (selanjutnya disingkat dengan al-Mawardi), Ahkam As-Sulthaniyah wa al-waliyat al-Diniyyah, (Beirut-Libanon:Dar al-Kutub 'Ilmiyah, t.t). hlm. 273.

${ }^{12}$ Muhammad Abu Zahrah, Al-Jarimatu wa al-'Uqubatu fi al-Fiwhi al-Islami, (Dar al-Fikri al'Arabi,t.tp, t.t), hlm. 26.

${ }_{13}$ Ibid.,

${ }^{14}$ Ibid.,
} 
Menurut 'Abd Qadir 'Audah, pengertian jināyah menurut istilah fiqh adalah perbuatan yang dilarang syara', baik perbuatan itu mengenai jiwa atau harta atau lainnya. ${ }^{15}$ Tetapi dia mengatakan bahwa kebanyakan ulama fiqh memakai kata jināyah dalam makna yang khusus, yaitu untuk perbuatan yang mengenai jiwa orang atau anggota badan, seperti membunuh, melukai dan memukul. ${ }^{16}$

Dari beberapa pendapat dapat disimpulkan bahwa Tindak pidana dalam hukum Islam disebut dengan jinayah yakni suatu tindakan yang dilarang oleh syara' karena dapat menimbulkan bahaya bagi jiwa, harta, keturunan, dan akal (intelegensia). Pengertian dari istilah jinayah mengacu pada hasil perbuatan seseorang dan dalam pengertian tersebut terbatas pada perbuatan yang dilarang. Umumnya para fuqaha menggunakan istilah tersebut hanya untuk perbuatan-perbuatan yang mengancam keselamatan jiwa seperti pemukulan, pembunuhan, dan sebagainya. Selain itu ada fuqaha yang membatasi istilah jinayah kepada perbuatan-perbuatan yang diancam dengan hukuman hudud dan Qishash, tidak termasuk perbuatan-perbuatan yang diancam dengan hukuman $t a$ 'zir, istilah lain yang sepadan dengan istilah jinayah adalah jarimah, yaitu larangan-larangan syara' yang diancam Allah dengan hukuman had atau ta'zir. ${ }^{17}$

\section{Kriteria Tindak Pidana Islam}

Berdasarkan pengertian tindak pidana (jināyah) di atas, maka dapat diambil kesimpulan bahwa suatu perbuatan itu dianggap sebagai tindak pidana, apabila perbuatan tersebut bisa merugikan diri sendiri dan orang lain, baik kerugian itu berkaitan dengan tata aturan masyarakat, harta benda, nama baik, perasaan atau pertimbangan lainnya yang dihormati dan dipelihara oleh masyarakat.

\footnotetext{
${ }^{15}$ Abd al-Qadir 'Audah, Al-Tasyri' al-Jinai al-Islami, Jld. II, (Beirut-Libanon: Muassasah al-Risalah, 1968), hlm. 4.

${ }^{16}$ Ibid.,

17 Yandi Maryandi, “Gagasan Pemberlakuan Pidana Islam di Indonesia”, Jurnal Tahkim, (Jurnal Peradaban dan Hukum Islam) 2017, hlm 25.
} 
TAHKIM, Jurnal Peradaban dan Hukum Islam. Vol.3 No.2 (0ktober, 2020) | ISSN : 2597-7962

Adapun mengenai kriteria suatu perbuatan dikatakan tindak pidana, 'Abd al-Qadir 'Audah sebagaimana dikemukakan juga oleh Muhammad Abu Zahrah, memformulasikan ke dalam tiga bentuk rukun (perkara), yaitu: ${ }^{18}$

a) Rukun syar' $i$ (undang-undang), yaitu adanya nash yang melarang suatu perbuatan dengan diancam hukuman kepadanya.

b) Rukun maddi, yaitu adanya tindakan

c) Rukun adabi, yaitu adanya perbuatan (orang mukallaf) yakni orang yang dapat dimintai pertanggungjawaban terhadap jarīmah yang dilakukannya.

\section{Ketetapan Hukuman Pidana Islam}

Berdasarkan berat ringannya hukuman atau pelanggaran yang dilakukan oleh seseorang maka hukum pidana Islam (jināyah atau jarimah) dibagi menjadi tiga macam golongan, yaitu:

a. Tindak pidana $h u d \bar{u} d$, yang sering diartikan sebagai hukum atau ketetapan Allah Swt. Orang yang melakukan tindak pidana ini akan dikenai hukuman sesuai dengan yang telah ditetapkan oleh Allah Swt, tidak bisa ditambah atau dikurangi.

Hukuman yang diberikan kepada para pelaku tindak pidana ḩudūd merupakan hak Allah Swt, yang tidak bisa dihapuskan, baik oleh perseorangan yang menjadi korban tindak pidana itu sendiri maupun oleh masyarakat yang diwakili lembaga negara.

Dalam hukum Islam dikenal tujuh macam tindak pidana ḥudūd, yaitu: zina, qażaf (menuduh orang berbuat zina), meminum minuman keras, mencuri, hirābah (orang yang memerangi Allah Swt, dan rasul-Nya), murtad, dan orang yang memberontak terhadap penguasa yang sah (bughāt).

b. Tindak pidana qiṣaș dan diyat (ganti rugi). Tindakan pidana ini berkenaan dengan kejahatan terhadap orang, seperti membunuh dan menganiaya, bagi pelaku tindak

${ }^{18}$ Abd al-Qadir 'Audah, Al-Tasyri' al-Jinai al-Islami., Hlm 4 
TAHKIM, Jurnal Peradaban dan Hukum Islam. Vol.3 No.2 (0ktober, 2020) | ISSN : 2597-7962

pidana ini akan dikenai hukuman qiṣ̄ạs atau diat dari individu yang menjadi korban. Kadar jumlah hukuman yang diberikan ditentukan oleh sang korban, namun tidak memiliki aturan batasan minimal atau maksimal.

Adapun tindak pidana qiṣāṣ dan diyat ini terbagi dalam lima macam, yakni: pembunuhan yang disengaja, pembunuhan yang menyerupai disengaja, pembunuhan tersalah, penganiayaan disengaja, penganiayaan yang tersalah. Penganiayaan yang dimaksud di sini adalah perbuatan yang tidak sampai menghilangkan jiwa sang korban, seperti melukai, memotong, merusak dll.

c. Tindak pidana $t a ' z \bar{\imath} r$. Berupa kejahatan yang tidak termasuk dalam hudūd dan qiṣașsdiyat, karena bentuk hukumannya diserahkan kepada kebijakan hakim. Istilah ta 'zīr ini bermakna memberikan pendidikan (pendisiplinan). Maksudnya adalah memberikan hukuman yang bertujuan mengoreksi atau merehabilitasi pelaku kejahatan. ${ }^{19}$

Hukum Islam tidak menentukan macam-macam hukuman untuk tiap-tiap tindak pidana ta'zīr, tetapi hanya menyebutkan sekumpulan hukuman, dari yang paling ringan sampai yang paling berat (min al-nuṣhi ilā al-ḥaddi). Dalam hal ini, hakim diberi kebebasan untuk memilih hukuman-hukuman yang sesuai dengan macam tindak pidana $t a ' z \bar{\imath} r$ serta keadaan si pelaku. Singkatnya, hukuman-hukuman tindak pidana $t a$ 'zīr tidak mempunyai batasan tertentu.

Jenis tindak pidana $t a ' z \bar{l} r$ tidak ditentukan banyaknya, seperti halnya tindak pidana hudūd dan qiṣass yang sudah ditentukan jumlah dan jenisnya. Hukum Islam sendiri hanya menentukan sebagian tindak pidana $t a ' z \bar{\imath} r$, seperti riba, mengkhianati janji, memaki orang, dan menyuap.

Adapun sebagian besar dari tindak pidana ta'zīr diserahkan kepada penguasa untuk menentukannya. Meski demikian, hukum Islam tidak memberikan wewenang kepada

\footnotetext{
${ }^{19}$ Hanafi, Asas-asas Hukum Pidana Islam, (Jakarta: Bulan Bintang, 1993), hlm. 7-8.
} 
penguasa untuk dapat menentukan tindak pidana dengan sekehendak hati, tetapi harus sesuai dengan kepentingan masyarakat dan tidak boleh berlawanan dengan ketentuan serta prinsipprinsip umum hukum Islam.

\section{Ketetapan Pidana Islam yang berkaitan dengan Narkoba}

Tujuan disyariatkannya hukum Islam adalah untuk mewujudkan dan memelihara kemaslahatan manusia yang ditekankan pada pemeliharaan lima sasaran pokok, yaitu agama, jiwa, akal, kehormatan dan keturunan, serta harta. Lima hal pokok ini wajib diwujudkan dan dipelihara jika seseorang menghendaki kehidupan yang berbahagia di dunia dan di hari kemudian, seperti ungkapannya dalam kitab al-Muwāfaqāt:

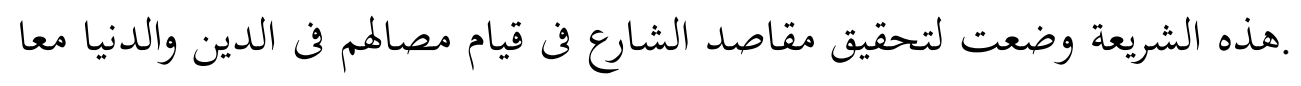

"Sesungguhnya syariat itu ditetapkan bertujuan untuk tegaknya (mewujudkan) kemaslahatan manusia di dunia dan akhirat”.

Ungkapan al-Syatibi "Hukum-hukum diundangkan untuk "الأحكام الثر عية لمصالح العباد" " kemaslahatan hamba" ${ }^{20}$ menegaskan bahwa doktrin maqāṣid al-syarī'ah adalah satu, yaitu maṣlaḥah atau kebaikan dan kesejahteraan umat manusia baik di dunia maupun di akhirat. Segala upaya untuk mewujudkan dan memelihara lima pokok tadi sebagai isi dari maqāṣid al-syarī'ah merupakan amalan saleh yang harus dilakukan oleh umat Islam. Sebaliknya, tindakan yang bisa mengancam keselamatan salah satu dari pokok tersebut dianggap sebagai tindakan kejahatan dan atau pelanggaran yang dilarang.

Dengan demikian jelaslah bahwa, tindakan kejahatan dapat dikategorikan ke dalam lima kelompok, yaitu kejahatan terhadap agama, kejahatan terhadap jiwa atau diri, kejahatan terhadap akal, kejahatan terhadap kehormatan dan keturunan, kejahatan terhadap harta benda. Masing-masing kejahatan itu diuraikan secara panjang lebar dalam literatur-literatur fikih dalam berbagai mazhab.

3.

${ }^{20}$ al-Syatibi, al-Muwāfaqāt fì 'Ușūl al-Syarī’ah, (Kairo: Mustafa Muhammad, t. th.), jilid. II, Hlm. 2- 
TAHKIM, Jurnal Peradaban dan Hukum Islam. Vol.3 No.2 (0ktober, 2020) | ISSN : 2597-7962

Kejahatan-kejahatan besar terhadap lima pokok ini diatur dalam bab jināyat. Jināyah atau jarimah, yaitu tindak pidana di dalam hukum Islam berupa larangan-larangan syara' yang diancam oleh Allah dengan hukuman hadd atau $t a ' z i \bar{r}$. Hukuman hadd adalah hukuman yang ditetapkan melalui wahyu yang merupakan hak Allah sebagai syari'. Hukuman ta'zīr adalah hukuman yang tidak ada nasnya, dan ditetapkan berdasarkan pertimbangan hakim (qā

Berkenan dengan tindakan kejahatan yang berkaitan dengan narkoba atau khamar, penulis membagi bentuk hukuman (sanksi) menjadi dua bagian yaitu:

a. Sanksi hukum bagi pengonsumsi atau pecandu.

Sanksi hukum yang diberlakukan kepada peminum/pengonsumsi khamar adalah hadd, yaitu didera (jilid) sebanyak 40 kali. Hal ini didasarkan atas hadits Nabi Saw:

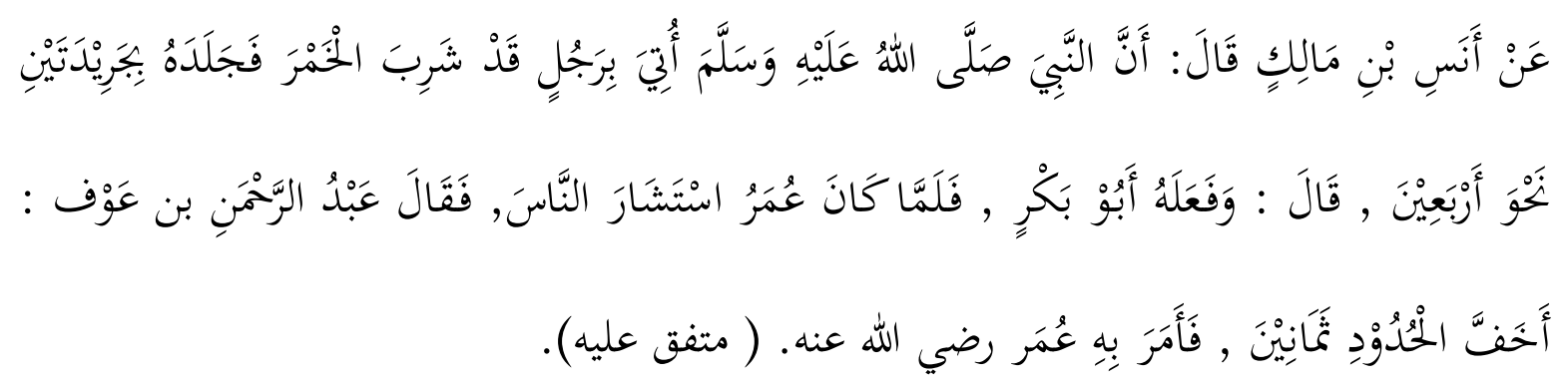

"Diriwayatkan dari Anas bin Malik ra, sesungguhnya Nabi Saw kedatangan seorang laki-laki yang telah meminum khamar kemudian Nabi Saw, menjilidnya dengan dua pelepah kurma sebanyak empat puluh kali. Anas berkata: dan Abu Bakar juga melakukannya (empat puluh kali jilid). Ketika Umar menemui peminum khamar, maka Abdurrahman bin 'Auf berkata: seringan-ringannya ḥudūd (batas hukuman meminum khamar) adalah delapan puluh kali, kemudian Umar memerintahkan (had meminum khamar) sebanyak delapan puluh kali." (HR. Bukhari dan Muslim). ${ }^{21}$

\footnotetext{
${ }^{21}$ Muhammad bin Ismail Al-Amir Ash-Shan'ani, Subulus Salam Syarah Bulughul Maram, Jilid 3 (Jakarta Timur:Darussunnah Press, 2009), Hlm 449.
} 
Dalam hal mengeksekusi hadd peminum khamar para sahabat menderanya dengan menggunakan pelepah kurma, sebagaimana dalam diriwayatkan dalam hadits:

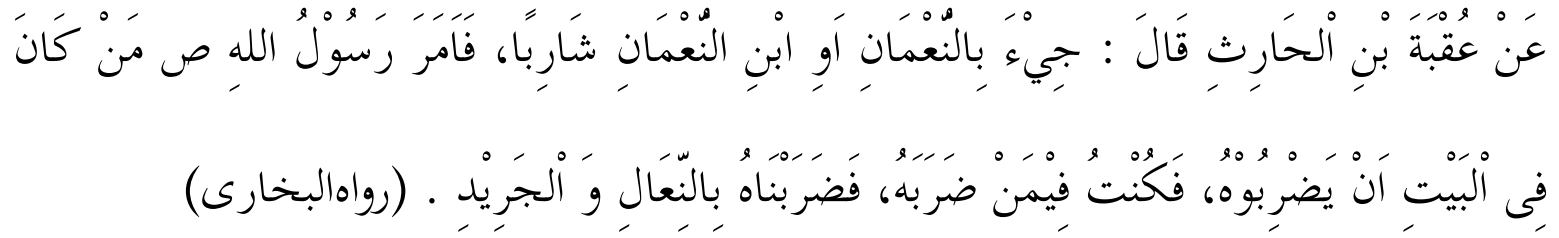

"Dari Uqbah bin Harist ra, katanya, telah didatangkan Nu'aiman atau Ibnu Nu'aimah, karena itu minum yang memabukkan, maka Rasulullah Saw, memerintahkan kepada orang yang di dalam rumah supaya memukulnya, maka Uqbah saja juga diantara orang-orang yang memukulnya lalu ia dipukul dengan terompah dan pelepah kurma," (HR. Bukhari). ${ }^{22}$

Jelaslah bahwa hukuman yang disyariatkan terhadap peminum khamar adalah pukulan yang dimaksudkan untuk menghinakan si peminum, menghardiknya dan membuat orang-orang menjauhi perbuatan itu. Sedangkan pukulan sebanyak 40 atau 80 kali adalah ijtihad dari para khalifah. Abu Bakar memilih 40 kali, sedangkan Umar 80 kali berdasarkan kesepakatan Abdurrahman bin Auf yang menyerupakan dengan hadd menuduh wanitawanita muḥșanāt (yang memelihara diri).

Sedangkan jika yang bersangkutan berulang kali mengonsumsi khamar maka hukumannya ditingkatkan menjadi hukum mati. Hal ini didasarkan pada hadits nabi berikut ini:

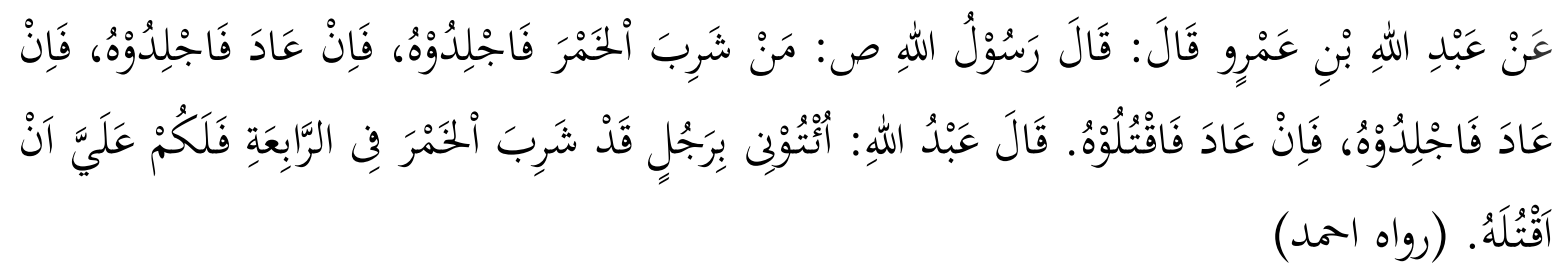

Dari 'Abdullah bin 'Amr, ia berkata : Rasulullah SAW bersabda, "Barangsiapa minum khamr maka deralah ia, kemudian jika kembali minum lagi, maka deralah dia, kemudian jika

\footnotetext{
${ }^{22}$ Muhammad Subhi bin Hasan Hallaq, Nailul Authar min Asrar Muntaqa al-Akhbar (Riyadh: Dar Ibn Taimiyah, 1427 H), hlm. 165.
} 
kembali lagi maka deralah dia, dan jika kembali minum lagi maka bunuhlah dia'. 'Abdullah berkata, "Bawalah kemari seseorang dari kalian yang minum khamr yang keempat kalinya, maka aku akan bunuh dia". [HR. Ahmad] ${ }^{23}$

Dari hadits di atas jika dicermati, bahwa peminum khamar yang mudaratnya yang ditimbulkannya hanya sebatas dirinya saja, keempat kalinya ia harus dihukum mati. Tentunya yang lebih dari itu, yaitu bagi para pedagang atau pemasok yang sudah jelas-jelas menimbulkan mudarat lebih luas tidak hanya menimpa perorangan, lebih layak mendapat vonis mati daripada peminum khamar.

b. Sanksi hukum bagi pengedar narkoba

Syariat Islam tidak hanya menjatuhkan hukuman atas penggunaan barang memabukkan semata, namun seluruh pihak yang terlibat dalam kasus penyalahgunaan juga terkena sanksi hukum. Abu Daud meriwayatkan dalam Sunannya dari Ibnu Umar ia berkata, Rasulullah Saw bersabda:

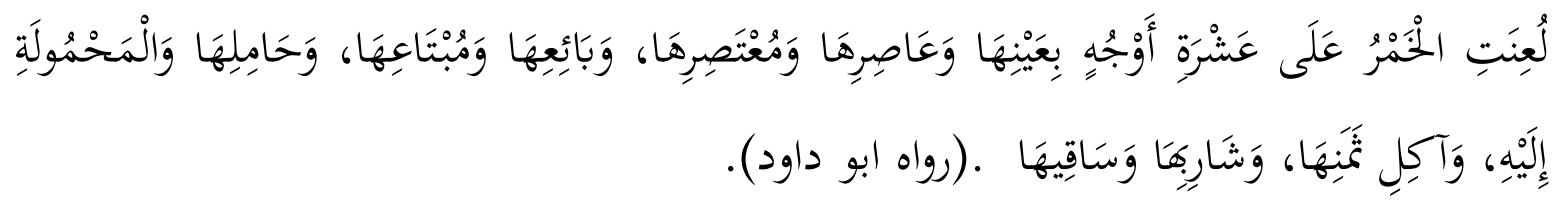

"Allah melaknat pemabuk khamar, penuang, penjual, pembeli, pemeras anggur, yang meminta diperaskan, yang membawa dan yang dibawakan," (HR. Abu Dawud). ${ }^{24}$

Kemudian apakah sanksi (hukuman) yang tepat untuk para pengedar pembuat, pengedar dan yang membuat peredaran narkoba dalam pandangan Islam. Menurut hemat penulis tergantung bagaimana kita melihat pelakunya.

Sebelum masuk kepada bagaimana hukuman yang tepat dalam Islam, terlebih dahulu penulis akan menyampaikan bagaimana sanksi menurut hukum positif di Indonesia bagi pengedar narkoba.

${ }^{23}$ Muhammad Abdurrahman bin Abdurrahim al-Mubarakfury, Muqaddimah Tuhfatul ahwadzi $b$ Syarh Jami’ al-Tirmidzi, tahqiq: Shidqy Muhammad Jamil al- 'Atthar (Beirut, Darul Fikr, 1995), Hlm 599.

${ }^{24}$ Shahih Ibnu Hibban Mukhraja, bab “dzikru istihqaqi la 'nillah jalla wa 'ala”,tth,juz 12, Hlm. 178 
TAHKIM, Jurnal Peradaban dan Hukum Islam. Vol.3 No.2 (0ktober, 2020) | ISSN : 2597-7962

Seperti telah diketahui bahwa kejahatan yang dilakukan oleh pengedar narkoba merupakan kejahatan yang luar biasa (extra ordinary crime) di mana kejahatan tersebut merupakan kejahatan transnasional yang terorganisir secara rapi yang dampaknya luar biasa, luas dan sporadis secara sistemik.

Di Indonesia, tindak pidana yang tergolong sebagai tindak pidana luar biasa (extraordinary crime) seperti tindak pidana terorisme, narkotika, korupsi, maupun illegal logging pantas dijatuhi pidana mati. Bukan hanya karena modus operandi tindak pidana tersebut yang sangat terorganisir, namun ekses negatif yang meluas dan sistematik bagi khalayak, menjadi titik tekan yang paling dirasakan masyarakat. Maka sebagai langkah yuridis yang menentukan eksistensi keberlakuan pidana hukuman mati di Indonesia, maka keluarlah putusan MK Nomor 2-3/PUUV/2007. ${ }^{25}$

Dalam hukum Islam, bahwa kategori kejahatan luar biasa adalah jarimah hirābah. Penetapan hirāabah sebagai jarīmah yang secara formal mengakibatkan ekses yang luas pada masyarakat didasarkan pada surat al-Māidah [5]: 33:

"Hukuman bagi orang-orang yang memerangi Allah dan Rasul-Nya dan membuat kerusakan di muka bumi, hanyalah dibunuh atau disalib, atau dipotong tangan dan kaki mereka secara silang atau diasingkan dari tempat kediamannya. Yang demikian itu kehinaan bagi mereka di dunia, dan di akhirat mereka mendapat azab yang besar," (QS. al-Māidah [5]: 33$)^{26}$

Selanjutnya, apakah para pengedar narkoba itu sama dengan kejahatan setingkat hirabah. Jika melalui kajian yang akurat ternyata disimpulkan bisa disamakan, maka berarti dia bagian dari bentuk hirabah yang penerapan sanksi hukumannya adalah hadd yaitu dibunuh, disalib, atau dipotong tangan dan kakinya secara bersilang dan seterusnya.

\footnotetext{
${ }^{25}$ Muhammad Rustamaji, Menyoal Eksistensi Pidana Hukuman Mati di Indonesia, http://rustamaji 1103, wordpress.com/2015/03/25/menyoal-eksistensi-pidana-hukuman-mati-diindonesia/diunduh pada tanggal 25 maret 2015 pukul $15.00 \mathrm{WIB}$

${ }^{26}$ Departemen Agama RI, Al-Qur'an dan Terjemah, Jakarta:Pustaka Al Fatih 2009, Hlm 113
} 
TAHKIM, Jurnal Peradaban dan Hukum Islam. Vol.3 No.2 (0ktober, 2020) | ISSN : 2597-7962

Jika kategori hirabah itu 'ilat hukumnya adalah يسعون فى الأ رض فسادا (berdampak luar biasa, luas dan sporadis serta sistematik kerusakannya), tampaknya pengedar narkoba dengan skala besar bisa dikategorikan sebagai hirabah, karena sama-sama menyebarkan kerusakan secara luas dan melawan hukum yang berlaku, memerangi Allah, menentang ajaran Rasulullah, dan dapat merusak tatanan negara.

Iman al-Suyuti dalam tafsirnya mengatakan bahwa yang dimaksud menyebarkan kerusakan di muka bumi itu modusnya bisa berbentuk perzinaan, pencurian, pembunuhan, merusak harta dan keturunan. ${ }^{27}$

Dengan demikian maka pengedar narkoba bisa dikategorikan sebagai bentuk hirabah yang sangat bertentangan dengan maqāṣid al-syarī'ah khususnya al-ḍarüriyyah al-khams dan karenanya maka sudah layak dihukum mati. Diberlakukannya hukuman mati kepada yang bersangkutan bukan melalui ketetapan ta'zīr tetapi melalui ketetapan hadd sebagai dinyatakan dalam surat al-Mā'idah ayat tiga.

\section{SIMPULAN}

1) Kebijakan Sanksi pidana mati terhadap tindak pidana narkotika merupakan salah satu eksistensi kedaulaulatan bangsa Indonesia sehingga tetap mempertahankan dan memerlukannya. Tindak pidana narkotika merupakan kejahatan yang berat dan serius, sangat merugikan bangsa dan negara dan merupakan bahaya yang sangat besar bagi kehidupan manusia, masyarakat, bangsa, dan negara serta ketahanan nasional Indonesia. Penjatuhan sanksi pidana mati merupakan benteng terakhir untuk menjaga keamanan dan ketertiban bangsa dan Negara Indonesia dan sebagai amputasi jaringan kejahata narkotika.

2) Penerapan sanksi pidana mati terhadap tindak pidana narkotika diberikan kepada penjahat narkotika sebagai Pembuat, Bandar dan pengedar. Bahwa sanksi pidana mati yang

\footnotetext{
${ }^{27}$ Abdurahman bin Abu Bakr al-Suyuthi, al-Dur al-Mans̄ūr fì al-Tafsīr bi al-Ma `̇ur, (Kairo: Dar Hijr, 2003), juz V, Hlm. 209.
} 
TAHKIM, Jurnal Peradaban dan Hukum Islam. Vol.3 No.2 (0ktober, 2020) | ISSN : 2597-7962

ada dalam Undang-Undang No.35 Tahun 2009 Tentang Narkotika adalah masih sangat relevan untuk diterapkan, karena kejahatan narkotika termasuk kedalam kejahatan berat dan serius serta mengacam kehidupan manusia.

3) Pada masa awal Islam makna khamar terbatas pada jenis minuman yang memabukkan yang terbuat dari perasaan anggur, korma, gandum dan sejenisnya. Namun demikian tidak berarti bahwa khamar terbatas pada apa yang muncul pada masa awal Islam itu tetapi lebih kepada bahwa bentuk yang ditemukan pada waktu itu masih sangat terbatas. Oleh karena itu, makna khamar selanjutnya mengalami perkembangan baik dari jenis, nama dan bahayanya sesuai dengan perkembangan jamannya.

4) Sanksi hukum yang berkaitan dengan penyalahgunaan Narkoba adalah ditetapkan berdasarkan hukum had $(h u d \bar{u} d)$. Pengonsumsinya didera sebanyak 40 kali dan sebagian sahabat menambahnya dengan 80 kali. Sedangkan jika berulang-ulang (pecandu) sampai melakukan 4 kali maka bisa dikenakan hukuman mati.

5) Dalam hukuman Islam, bagi pengedar narkoba dengan skala tertentu bisa dikategorikan tindak pidana hirāäbah, kejahatan luar biasa besar (ekstra ordinary crime) dan karenanya diancam dengan hukuman ḥudūd sampai pada hukuman mati. Hal ini sesuai dengan semangat maqāṣid al-syarī'ah khususnya menyangkut al-darūriyyah al-khams.

\section{DAFTAR PUSTAKA}

Ash-Shan'ani, M. A, (2009). Subulus Salam Syarah Bulughul Maram, Jakarta Timur:Darussunnah Press.

'Audah, A (1968), Al-Tasyri' al-Jinai al-Islami, Beirut-Libanon: Muassasah alRisalah.

Al-Zuhaili, W. (1989). Al-Fiqh al-Islami wa Adillatuhu, Jld. VI. Damsyik: Dar alFikr.

Al-Suyuthi, A. (2003). al-Dur al-Mans்ūr fì al-Tafsīr bi al-Ma`̀̇ur, Kairo: Dar Hijr. 
TAHKIM, Jurnal Peradaban dan Hukum Islam. Vol.3 No.2 (0ktober, 2020) | ISSN : 2597-7962

Barda, A. (2002). Bunga Rampai Kebijakan Hukum Pidana. Bandung : PT Citra Aditya Bakti.

Departemen Agama RI, (2009). Al-Qur'an dan Terjemah, Jakarta:Pustaka Al Fatih.

Hanafi, (1993). Asas-asas Hukum Pidana Islam, Jakarta: Bulan Bintang.

Muladi, (1997) . Hak Asasi Manusia, Politik dan dan Sistim Peradilan, Semarang: Undip.

Barda, N. A. (2005). Pembaharuan Hukum Pidana Dalam Perspektif Kajian Perbandingan. Bandung: PT Citra Aditya Bakri.

\section{Jurnal}

Abdurrahim, M.H. (2016). Hukuman Mati Problem Legalitas dan Kemanusiaan, Jurnal Transisi, vol. X, p. 28, Januari.

Purnomo, A. (2016). "Hukuman Mati Bagi Tindak Pidana Narkoba di Indonesia : Persfektif Sosiologi Agama," De Jure : Jurnal Hukum dan Syariah, vol. 8, pp. 15-23, Juni. Maryandi, Y. (2017) . Gagasan Pemberlakuan Hukum Pidana Islam di Indonesia”, TAHKIM: Jurnal Peradaban dan Hukum Islam, Oktober. 